\title{
Renal Oncocytoma with Invasive Histopathologic Features - Case Report
}

\section{Renálny onkocytóm s histologickými črtami invázie - kazuistika}

\author{
Kolníková G. ${ }^{1}$, Marinová P. ${ }^{1}$, Gál V. ${ }^{1}$, Mečiarová I. ${ }^{1}$, Mišanko V. ${ }^{2}$, Rampalová J. ${ }^{1}$, Jáni P. ${ }^{1}$, Orthová S. ${ }^{1}$, \\ Ondriaš F. ${ }^{1}$, Caňo M. ${ }^{2}$ \\ 1 Division of Pathology, Alpha Medical Patologia l.t.d., Bratislava-Ružinov, Slovak Republic \\ ${ }^{2}$ Department of Urology, University Hospital Bratislava-Ružinov, Slovak Republic
}

\begin{abstract}
Summary
Background: Renal oncocytoma is an uncommon tumor, classified as a benign renal neoplasm in the World Health Organisation classification of renal tumours. Despite it there were described several reports with invasive histopathologic features. Case report: We describe a case of renal oncocytoma with bizzare cells and invasion of renal sinus fat tissue. We performed immunohistochemical analysis of the case and a review of relevant literature. Conclusion: In order to set up the right diagnosis the perfect co-operation of clinicians and pathologists is necessary. In our opinion, in accordance with other authors, the renal oncocytomas should be considered as having a very low rather than no malignant potential, in spite of clinically benign behavior, supplementing a hypothesis, whether renal oncocytomas may be considered as a precancerous lesion of chromophobe carcinoma.
\end{abstract}

\section{Key words}

renal oncocytoma - invasion - immunohistochemistry - genetics

\section{Súhrn:}

Úvod: Renálny onkocytóm je zriedkavý tumor, ktorý podla WHO klasifikácie patrí medzi benígne obličkové novotvary. Napriek tejto skutočnosti boli v literatúre popísané prípady s histologickými črtami invázie. Prípad: Popísali sme prípad renálneho onkocytómu s bizardnými bunkami a so známkami invázie do sínusového tukového tkaniva obličky. Urobili sme imunohistechemickú analýzu prípadu a prehlad príslušnej literatúry. Záver: Aby bolo možné sa dopracovat' k správnej diagnóze je nevyhnutná kvalitná týmová spolupráca patológa a klinika. V súlade $s$ inými autormi sa domnievame, že renálny onkocytóm by mal byt považovaný skôr za nádor s nízkym malígnym potenciálom ako za nádor bez malígneho potenciálu. Napriek jeho klinicky benígnemu charakteru by na základe hypotézy bolo možné renálny onkocytóm považovat’ za prekancerózu chromofóbneho karcinómu obličky.

\section{Klúčové slová}

renálny onkocytóm - invázia - immunohistochémia - genetika
Autoři deklarují, že v souvislosti s předmětem studie nemají žádné komerční zájmy.

The authors declare they have no potential conflicts of interest concerning drugs, products, or services used in the study.

Redakční rada potvrzuje, že rukopis práce splnil ICMJE kritéria pro publikace zasílané do biomedicínských časopisů.

The Editorial Board declares that the manuscript met the ICMJE "uniform requirements" for biomedical papers.

झ"

MUDr. Georgína Kolníková

Division of Pathology

Alpha Medical Pathologia Ltd

Ružinovská 6

82606 Bratislava

Slovak Republic

e-mail: mudr.kolnikova@gmail.com

Submitted/Obdrženo: 21. 11. 2013

Accepted/Přijato: 1. 12. 2013 


\section{Introduction}

Renal oncocytoma is classified as a benign renal neoplasm in the WHO classification of renal tumors [1]. Renal oncocytoma is the second most common benign renal neoplasm after angiomyolipoma, comprising 3-7\% of all renal tumors [2]. Most renal oncocytomas are asymptomatic at presentation with discovery occurring during radiographic work-up of unrelated conditions. Few patients present with hematuria, flank plain or palpable mass [1-3]. There is a wide range of age distribution, with a peak incidence in the 7th decade of life. Male to female ratio is $2: 1$. Zhou et al [4] defined renal oncocytoma as a benign epithelial neoplasm composed of round-to polygonal-cells with abundant mitochondria-rich eosinophilic cytoplasm, thought to arise from the intercalated cells in the kidney. It is considered to be a benign tumor with an excellent prognosis $[1,5,6]$. Extension to perinephric fat without stromal response can occur (20\%). Extension into renal veins is reported in up to $5 \%$ of cases [4]. In this report, we describe a case of a 69-year-old man with renal oncocytoma with bizarre cells and with invasion to the perirenal fat tissue. Computer tomography (CT) examination also discovered three nodular lesions in the lungs. Preconception that there are metastatic lesions of renal oncocytoma was not verified. Histological examinations revealed the squamocellular carninoma of the lungs, which means tumor duplicity. We performed immunohistochemical analysis and a review of relevant literature about dualistic benign/malignant features of renal oncocytoma.

\section{Clinical findings}

A 69-year-old man (smoker) presented with stabbing, spot-like abdominal pain in the epigastrium. The patient noted that the pain is getting more severe, irradiating to the back. Excessive sweating, vomiting was also experienced. The patient did not observe blood in urine. Abdominal USG examination showed mild hepatosplenomegaly and a $9.1 \times 8.4 \times 10 \mathrm{~cm}$ tumor with non-homogeneous density in the right kidney with small calcifications. Left kidney

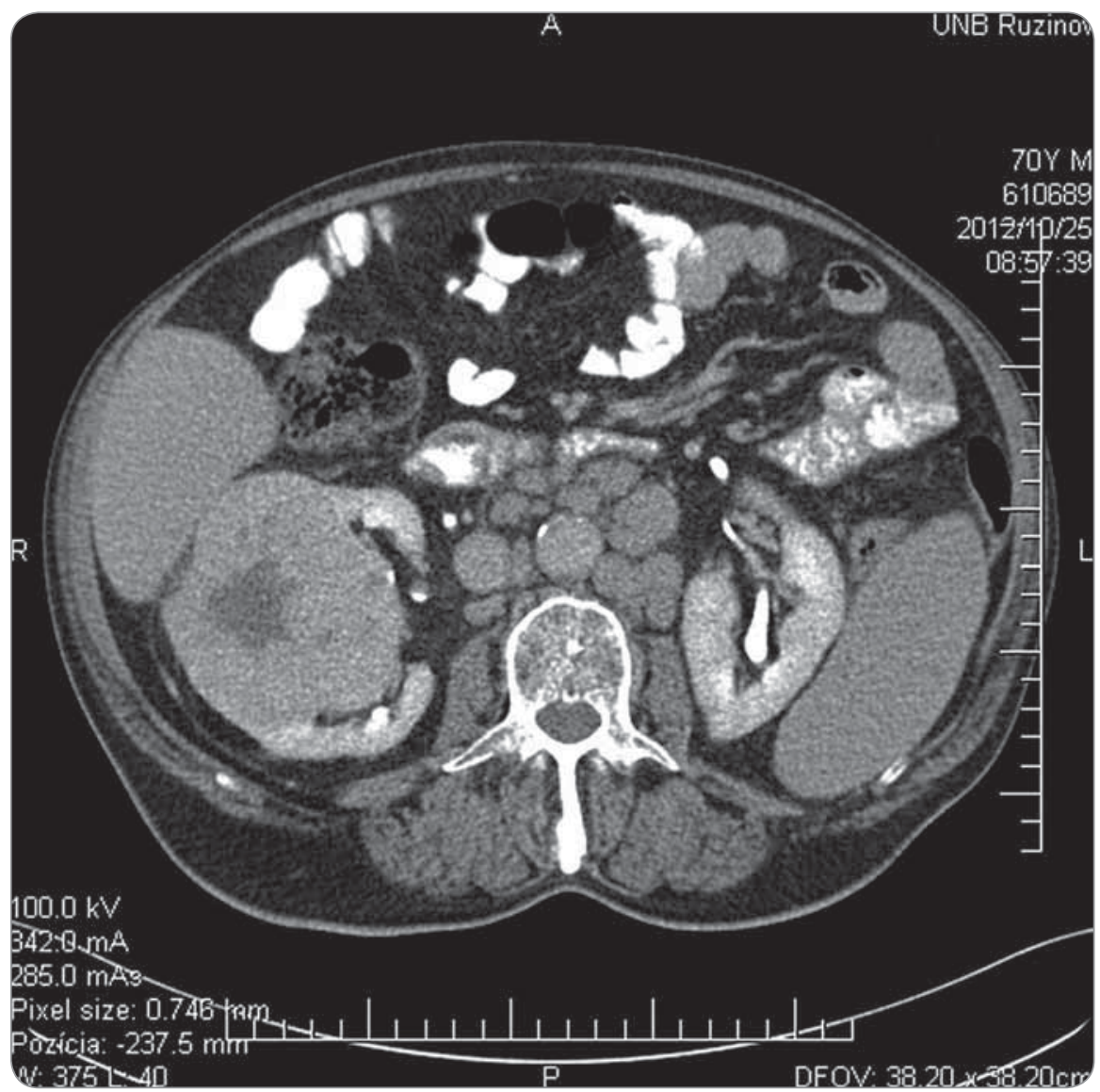

Fig. 1. CT examination of abdomen.

contained some cysts of $3.5 \mathrm{~cm}$ maximal size. Lymphatic nodes in the retroperitoneum were $3 \mathrm{~cm}$ maximum. CT examination (Fig. 1) confirmed the USG exam of the abdomen and three well-limited lesions in the lungs which were previously not discovered at radiography exam ( $8 \mathrm{~mm}$ nodule in the left lung, $15 \mathrm{~mm}$ in the hilus of the left lung and $20 \mathrm{~mm}$ in the right lung with basal localization).

Radical nephrectomy was carried out on the right side (11/2012), and then nodulectomies (1/2013) were carried out in the lungs.

\section{Pathology findings}

The renal tumor was in the upper and the midzone of the kidney, measuring up to $9 \mathrm{~cm}$ in diameter. The tumor was yellow-brown in color with a central white scar, $1.8 \mathrm{~cm}$ in diameter. Histology showed microscopic features of oncocytoma, packets of regular cells with eosinophilic cytoplasm with cystic changes, without mitotic figures (0/10 HPF). There were binucleated and bizarre cells, too (Fig. 2).
Hale colloidal iron showed an intraluminal staining. Invasion of renal sinus fat tissue was also detected (Fig. 3).

Immunohistochemical analysis Tumor cells had negative immunoreactivity for RCC (renal cell carcinoma antigen), CD10, CK7 (cytokeratin 7), AMACR, Vimentin and positive for CD117, CK 7, E-cadherin and EMA (epithelial membrane antigen). Proliferation marker Ki 67 was minimal.

Our diagnostic conclusion was an oncocytoma with invasive histologic features. Nine weeks later we got resections of lung with nodules. Our diagnosis, based on the immunohistochemical analysis, was squamocellular carcinoma probably of the lung with intrapulmonal metastasion; thus, the patient had two types of tumous. Unfortunately, there was no genetic analysis.

\section{Current state}

Therapy of the oncocytoma is radical nephrectomy, which was carried out on the 
patient. Therapy is now centered on the squamocellular carcinoma of the lungs patient received five cycles using carboplatin and gemcitabine for four months, then tyrosine-kinase inhibitor (erlotinib) for four months. Twelve months after nephrectomy, the patient is doing well.

\section{Discussion}

Renal oncocytoma was first described by Zippel in 1942; in 1976, Klein and Valensi demonstrated its benign character with excellent prognosis $[7,8]$.

Renal oncocytomas in general are typically solid, well circumscribed but nonencapsulated solid masses of mahogany or dark brown colour. They often have a central stellate scar and can reach a huge size. They can be multicentric and bilateral [1,4,9-11].

Histopathologically, the tumor is characterized by a proliferation of oncocytic renal epithelial cells displaying alveolar, tubular or cystic patterns, composed of cells with abundant acidophilic granular cytoplasm. The nuclei usually have smooth round or oval contours, focal nuclear polymorphism can also occur. The typical case of oncocytoma should not contain prominent papillary formations, clear cells, cystic changes, hemorrhage or necrosis. Psammoma bodies can be present. Some renal oncocytomas may be multifocal (oncocytosis) and display changes suggestive of chromophobe cell carcinoma $[4,11]$. Our purpose was to exclude heterogenecity (we examined almost 50 specimens) and to exclude chromophobe or clear cell renal cell carcinoma. It is essential to examine the whole tumor, if possible, because renal cell carcinoma can be present in the same oncocytoma as well $[6,9]$. Oncocytomas and chromophobe renal cell carcinomas are closely related tumors since they originate from the intercalated ducts of the distal nephron, but they may be morphologically difficult to differentiate by hematoxylin eosin staining. Colloidal iron helps to differentiate the reticular staining of chromophobe carcinoma from the weak granular or absent staining of oncocytoma. Cytokeratin 7 was reported to be positive in chromophobe carcinomas and negative in renal oncocytomas $[4,10,11]$, Zhou et

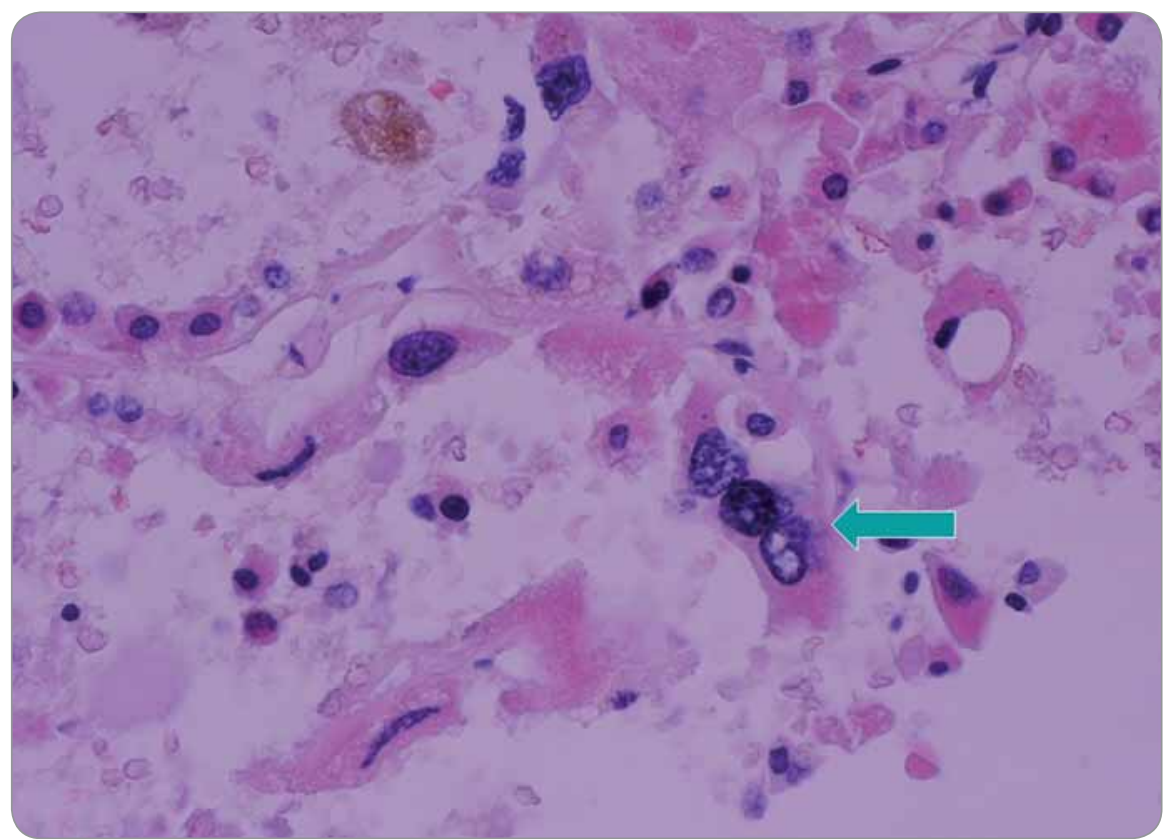

Fig. 2. Bizarre cells in oncocytoma.

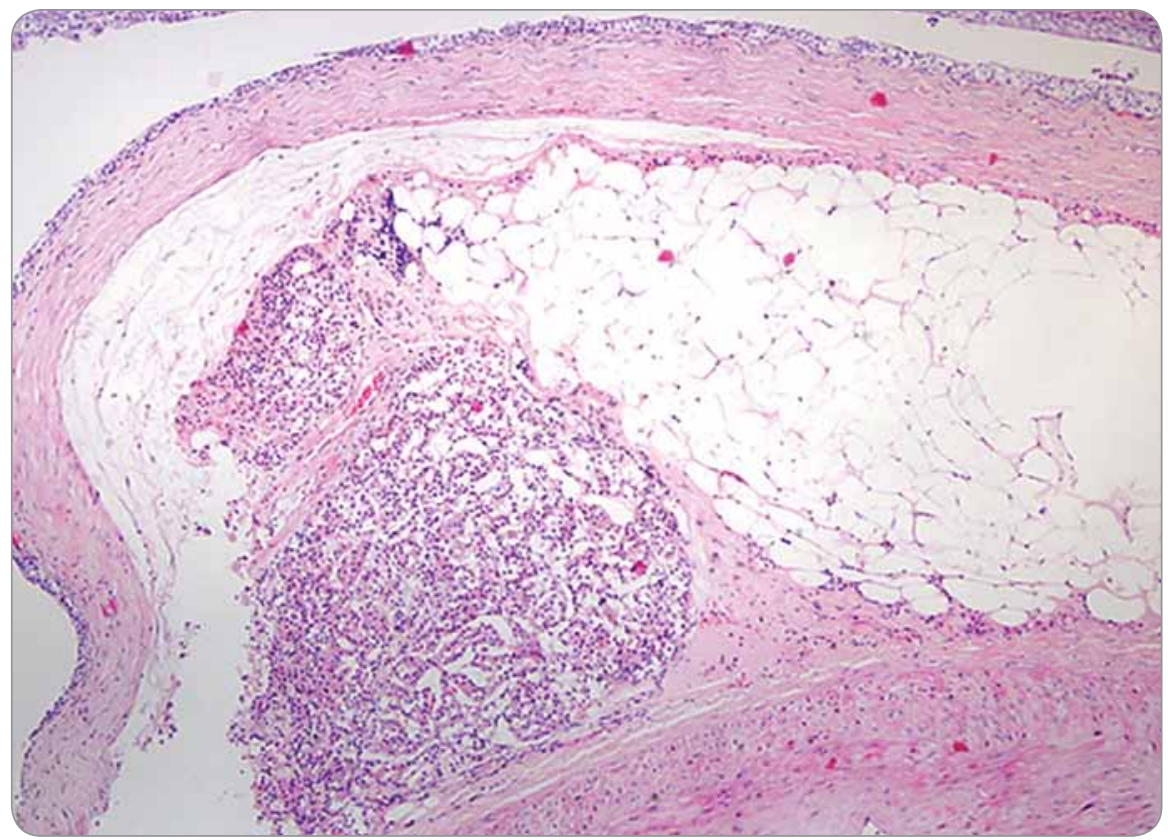

Fig. 3. Invasion of renal sinus fat tissue.

al [4] described that cytokeratin 7 is negative or positive in single cells or small clusters of cells.

EMA is expressed similarly by oncocytomas and chromophobe carcinomas [13].

CD10 is negative in all renal carcinomas. Liu et al [14] described a little benefit of CD 10 in the separation of clear cell RCC from chromophobe RCC and oncocytoma. Vimentin is negative in all oncocytomas and in $79 \%$ of the chromophobe carcinomas, although focal positivity can be seen in tumor cells within septa [4]. Mazal et al [15] examined a kidney specific cadherin, a cell adhesion molecule found on the basolateral membrane of renal tubular epithelial cells and collecting duct cells. Their conclusion was that kidney specific cadherin was expressed almost exclusively in chromophobe carcinomas. 
Tab. 1. Diagnostic strategy recommend by Liu et al [14].

\begin{tabular}{|c|c|c|c|c|}
\hline \multicolumn{5}{|l|}{ 1st step: } \\
\hline & & Vimentin & GST a & CD 117 \\
\hline \multicolumn{2}{|c|}{ onkocytoma and chromophobe RCC } & neg. & neg. & pos. \\
\hline \multicolumn{2}{|l|}{ clear cell RCC } & pos. & pos. & neg. \\
\hline \multicolumn{5}{|l|}{ 2nd step: } \\
\hline & \multicolumn{2}{|c|}{ Hale Colloidal Iron } & CK 7 & EpCAM \\
\hline chromophobe RCC & \multicolumn{2}{|c|}{ pos. } & pos. & neg. \\
\hline onkocytoma & \multicolumn{2}{|c|}{ neg. } & neg. & neg. \\
\hline
\end{tabular}

CD 117 is diffusely positive - the study of Liu et al [14] confirmed the accuracy of CD117 and its expression in chromophobe RCC and oncocytoma, in contrast with negative staining in clear cell RCC. Glutathion S-transferase A (GST A) and epithelial cell adhesion molecule (EpCAM) are also useful markers, Liu et al [14] recommend a combination of three markers - vimentin, GSTa and EpCAM for the differential diagnosis of chromophobe carcinoma, oncocytoma and a clear cell carcinoma. In their study, they achieved $100 \%$ sensitivity and 100\% specificity. CD117 and CK7 could be used as second line markers for the differential diagnosis, with high specificity (100\%) and high sensitivity $(90 \%$, $86 \%$, resp.) (Tab. 1).

There have been extensive reports on the biological behavior and histological features of renal oncocytomas since they were first described over 70 years ago. In a large retrospective study, Lieber et al [16] stratified 90 tumors that fitted the criteria of oncocytoma and pro- posed the grading system described in Tab. 2.

Although Amin et al revalued tumors with grade 2 and 3 in Lieber's study as chromophobe cell carcinomas [17], we think that our case may classified as grade 2 . Since 2000 we have diagnosed 32 cases of oncocytoma, there was an only case with invasive histopathologic features.

Concern for possible malignant potential of renal oncocytoma, described for the first time by Fairchild et al [12], was implied by several observations (mild nuclear pleomorphism oncocytoma, ultrastructural characteristics suggested, the oncocytoma originated from proximal tubular cells that gave rise to the renal carcinoma, then multifocal potential and coexistence of oncocytoma and chromophobe renal carcinoma in contralateral kidney).

Since then, only rare cases of metastatic oncocytomas have been described $[18,19]$ and unique cases have been studied with a modern panel of immunohistochemistry, so called metastatic oncocytomas were probably chromophobe renal cell carcinomas or granular

Tab. 2. Grading system of renal cell oncocytomas [16].

\section{Cell atypia}

grade 1 grade 2

grade 3 closely packed, regular appearing cells more cellular variation

cellular variation

\section{Nuclear atypia}

rounded smooth nuclei irregular nuclei

significant nuclear atypia
Mitotic figures

0

0

possible mitotic figures

Tab. 3. Presence of malignant features in a large series of oncocytomas [20].

\begin{tabular}{|c|c|c|c|c|}
\hline Reference & Year & Number of cases & $\begin{array}{l}\text { Perinephric invasion } \\
\text { ( } \mathrm{n} \%)\end{array}$ & $\begin{array}{c}\text { Metastasis } \\
\text { (histologically confirmed) }\end{array}$ \\
\hline Davies et al [21] & 1991 & 166 & $18(10)$ & 0 \\
\hline Hartwick et al [22] & 1992 & 23 & $0(0)$ & 0 \\
\hline Amin et al [17] & 1997 & 80 & $11(14)$ & 0 \\
\hline Perez-Ordonez et al [23] & 1997 & 70 & $14(20)$ & 1 \\
\hline Dechet et al [24] & 1999 & 138 & $0(0)$ & 0 \\
\hline Romis et al [25] & 2004 & 32 & $0(0)$ & 0 \\
\hline Gudbjartsson et al [26] & 2005 & 45 & $1(2)$ & 0 \\
\hline our department & 2013 & 32 & $1(3)$ & 0 \\
\hline
\end{tabular}


forms of clear cell renal carcinoma with incorrect histology classification $[6,19]$.

Oncocytic tumors of other organs e.g. those of the adrenal or salivary gland - may occasionally show malignant behavior, but this is associated with cytonuclear and histological features indicative of malignant behavior (Tab. 3) [20].

From a genetic point of view, oncocytomas are heterogeneous, and a subset of $(10 \%$ of them) shows loss of heterozygosity for chromosome 1 and/or chromosome $\mathrm{X}$ and/or 14, whereas another subset is characterized by translocation involving chromosome 11. The abnormalities on chromosome 1 are shared with chromophobe RCC, which also carry additional chromosomal changes. This observation has led to hypothesis that oncocytomas may progress to chromophobe renal cell carcinomas [20]. Al-Saleem et al [27] report a case of a 69-year-old male with numerous oncocytic neoplasms of both kidneys, morphologically progressing from oncocytomas to hybrid tumors with chromophobe carcinomas (not associated with Birt Hogg Dube syndrome). Their hypothesis was that renal oncocytosis and possibly familial oncocytomas demonstrated multiple chromosomal losses associated with evidence of progression to chromophobe renal cell carcinoma in the same tumor, the same kidney, or in the contralateral kidney [27].

\section{Conclusion}

In conclusion, a subset of oncocytomas sharing genetic or molecular features of chromophobe carcinoma may explain rare instances of invasive histologic features or metastases, although the presence of these features does not necessarily imply clinically malignant behavior [20]. We agree with Oxley et al [19] that renal oncocytomas should be considered as having a very low rather than no malignant potential, raising again the question, whether renal oncocytomas may be considered as a precancerous lesion of chromophobe carcinoma. In order to set up with the right diagnosis, perfect co-operation of clinicians and pathologists is necessary. Radical nephrectomy could be regarded as an overtreatment, especially in patients with small tumors, but coexisting renal cell carcinoma, perirenal fat invasion, a hallmark of malignant behavior, might indicate radical surgery in these patients [26]. It is essential to analyze the whole tumor, if possible. Fine needle biopsy, aspiration cytology and frozen section biopsy are inappropriate methods for correct morphologic diagnosis $[6,28]$. The co-operation between clinicians and pathologists and the clinical observation of patients with renal oncocytoma will lead to improved patient management and ultimately better patient care.

\section{References}

1. Reuter VE, Davis CJ, Moch H. Onkocytoma. In: Eble JN Sauter G, Epstein JI (eds). World Health organisation classification of tumours: pathology and genetics of tumours of the urinary system and male genital organs. Lyon: IARC Press 2004: 42-43.

2. Rosenkratz AB, Hindmann N, Fitzgerald EF et al. MR features of renal oncocytoma and chromophobe renal cell carcinoma. AJR Am J Roentgenol 2010; 195(6): W421-W427.

3. Lamla A, Pernička J. Benigní nádory ledvin. Urolog pro Praxi 2003; 3(3): 90-93.

4. Zhou M, Netto GJ, Epstein Jl. Oncocytoma. In: Zhou M Netto GJ, Epstein Jl (eds). Uropathology. Philadelphia: Elsevier Saunders 2012: 267-269.

5. Fabišovský M, Krhut J, Fikoczek H et al. Renal Oncocy toma: Evaluation our file of patients and CT findings. Ces Urol 2011; 15(4): 237-243.

6. Hora M, Ouda Z, Hes O et al. Onkocytom ledviny nádor jednoznačně benigní. Ces Urol 2000; 4(2): 30-32.

7. Zippel L. Zur kenntnis der onkocyten. Virchows Arch Pathol Anat 1942; 308: 360-382.

8. Klein MJ, Valensi QJ. Proximal tubular adenomas of kidney with so-called oncocytic features: A clinicopathological study of 13 cases of a rarely reorted neoplasm. Cancer 1976; 38(2): 906-914

9. Hes O, Michal M, Šulc M et al. Onkocytom ledviny morfologická variabilita 102 prípadů. Česk Patol 2001; 37(2): 51-56.

10. Michal M, Hes $O$, Mukenšnabl P. Renální onkocytom. In: Michal M, Hes $O$, Mukenšnábl P (eds)
Nádory ledvin dospělého věku. Plzeň: Euroverlag 2000: 55-65.

11. Ordonez NG, Rosai J. Chromophobe renal cell carcinoma. Oncocytoma 1195-1197. In: Rosai J (ed.). Rosai and Ackerman's surgical pathology I. 10th ed. Mosby Elsevier Inc 2011: 1189-1191, 1195-1197.

12. Fairchild TN, Dail DH, Brannen GE. Renal oncocytoma - bilateral multifocal. Urology 1983; 22(4): 355-359. 13. Pan CC, Chen PC, Ho DM. The diagnostic utility of MOC31, BerEP4, RCC marker and CD10 in the classification of renal cell carcinoma and renal oncocytoma; an immunohistochemical analysis of 328 cases. Histopathology 2004; 45(5): 452-459.

14. Liu L, Qian J, Singh H et al. Immunohistochemical analysis of chromofobe renal cell carcinoma, renal oncocytoma and clear cell carcinoma: an optimal and practical panel for differential diagnosis. Arch Pathol Lab Med 2007; 131(8): 1290-1297.

15. Mazal PR, Exner M, Haitel A et al. Expression of kidney specific cadherin distuingushes chrompophobe renal cell carcinoma from renal oncocytoma. Hum Pathol 2005; 36(1): 22-28.

16. Lieber MM, Tomera KM, Farrow GM. Renal oncocytoma. J Urol 1981; 125(4): 481-485.

17. Amin MB, Crotty TB, Tickoo SK et al. Renal oncocytoma: a reappraisal of morphologic features with clinicopathologic findings in 80 cases. Am J Surg Pathol 1997; 21(1): 1-12.

18. Amin R, Anthony P. Metastatic renal oncocytoma: a case report and review of the literature. Clin Oncol 1999; 11(4): $277-279$

19. Oxley JD, Sullivan J, Mitchelmore A et al. Metastatic renal oncocytoma. J Clin Pathol 2007; 60(6): 720-722.

20. Van der Kwast T, Perez-Ordonez B. Renal oncocytoma, yet another tumor that does not fit in the dualistic benign malign paradigm? J Clin Pathol 2007; 60(6): 585-586. 21. Davis CJ, Sesterhenn IA, Mostofi FK et al. Renal oncocytoma: clinicopathological study of 166 patients. J Urogenital Pathol 1991; 1: 41-52.

22. Hartwick RW, el-Naggar AK, Ro JY et al. Renal oncocytoma and granular renal cell carcinoma. A comparativ clinicopathologic and DNA flow cytometric study. Am J Clin Path 1992; 98(6): 587-593.

23. Perez-Ordonez B, Hamed G, Campbell S et al. Renal oncocytoma: a clinicopathologic study of 70 cases. Am J Surg Pathol 1997; 21(8): 871-883.

24. Dechet CB, Bostwick DG, Blute ML et al. Renal oncocytoma: multifocality, bilateralism, metachronous tumor development and coexistent renal cell carcinoma. J Urol 1999; 162(1): 40-42.

25. Romis L, Cindolo L, Patard JJ et al. Frequency, clinical presentation and evalution of renal oncocytomas: multicentric experience from a Europian database. Eur Urol 2004; 45(1): 53-57.

26. Gudbjartsson T, Hardarson S, Petursdottir V et al. Renal oncocytoma: a clinicopathological analysis of 45 consecutive cases. BJU Int 2005; 96(9): 1275-1279.

27. Al-Saleem T, Cairns P, Dulaimi EA et al. The genetics of renal oncocytosis: a possible model for neoplastic progression. Cancer Genet Cytogenet 2004; 152(1): 23-28.

28. Barnes CA, Beckman EN. Renal oncocytoma and its congeners. Am J Clin Pathol 1983; 79(3): 312-318. 